\title{
Unsur budaya kaum lain sebagai Jati Diri Kebangsaan dan pemersatu bangsa Malaysia dalam sajak pilihan terbitan Dewan Bahasa dan Pustaka
}

\begin{abstract}
ABSTRAK
Jati Diri Kebangsaan (JDK) ialah teras pembinaan negara bangsa khususnya bagi rakyat yang terdiri daripada pelbagai kaum dan berlainan latar budaya seperti di Malaysia. Oleh sebab itu, pemahaman dan penghayatan masyarakat terhadap JDK menjadi tonggak penting kepada negara. Kajian ini bertujuan menganalisis jati diri kebangsaan dalam sajak yang dikaji dan seterusnya merumuskan pelestarian jati diri kebangsaan dalam sajak terbitan Dewan Bahasa dan Pustaka. Kajian ini dilakukan secara kaedah membaca teliti dan secara analisis kandungan terhadap sajak-sajak terpilih terbitan DBP dari tahun 2010 sehingga tahun 2015. Analisis kajian menggunakan prinsip Dasar Kebudayaan Kebangsaan 1971 sebagai kerangka konseptual dengan menumpukan pada aspek unsur budaya kaum lain sebagai elemen JDK. Dapatan kajian mendapati sajak yang dikaji memperakukan bahawa unsur kebudayaan kaum lain bebas diamalkan, manakala unsur budaya kaum lain yang sesuai berdasarkan prinsip DKK menjadi elemen pemersatu rakyat dan pemangkin semangat JDK di Malaysia.
\end{abstract}

Kata Kunci: Jati diri kebangsaan; Bangsa Malaysia; Dasar Kebudayaan Kebangsaan; Dewan Bahasa dan Pustaka 